\title{
Pronghorn Reactions to Winter Sheep Grazing, Plant Communities, and Topography in the Great Basin
}

\author{
WARREN P. CLARY AND DONALD M. BEALE
}

\section{Abstract}

The winter distribution of pronghorn over $a 142-\mathrm{km}^{2}$ area on the Desert Experimental Range was significantly related to sheep grazing during the current winter, presence of black sagebrush, and topozraphic characteristics. Even moderate sheep use during the dormant period left grazing units relatively unfavorable for pronghorn until spring regrowth-at least on ranges where key pronghorn forage plants were in short supply. Winter use areas preferred by pronghorn were above the valley bottoms in rolling to broken topography where black sagebrush communities were evident. Movement characteristics of pronghom have allowed many of them to readily locate rested grazing units, and, therefore, avoid severe dietary competition with sheep.

The Great Basin and other parts of the Intermountain West contain about 16 million ha of low-shrub cold desert. Most of these lands are publicly owned, and their primary use has traditionally been the grazing of sheep in winter and cattle in various seasons. In the last decade or so land managers have intensified efforts to consider the needs of wild animals, and require specific information to consistently make good management decisions. Information is available on pronghorn diets, water requirements, and predator losses (Beale and Holmgren 1975, Beale and Smith 1970, Beale and Smith 1973), but no intensive study has been accomplished in the Great Basin region to document the effects of livestock grazing systems on pronghorn (Antilocapra americana) populations Kindschy et al. 1978). Neither have the impact of other uses of the low-shrub desert on pronghorn been well documented for the Great Basin. A study to probe the effects of winter sheep grazing and certain environmental factors on pronghorn distribution wasconducted on the USDA Forest Service Desert Experimental Range near Milford, Utah, during the winters of 1976-81.

Pronghorns thrive best on ranges with a diversity of grass-forbshrub communities (Autenrieth 1978), but are widely adaptable to different forage conditions across the total range of the species. The severity of competition between pronghorns and domestic livestock appears to vary greatly with differences in species of livestock, season of the year, and plant species available to the foraging ruminants (Salwasser 1980, Yoakum 1980). Although pronghorn habitat has mainly been manipulated by livestock grazing, many proposed energy, mineral, and defense activities threaten severe habitat disruptions. Winter ranges are often especially critical for pronghorn and are of particular concern (Kindschy et al. 1978). When the most important plants in the pronghorn's diet are a minor component of the vegetation, widespread surface disturbances or intensive sheep grazing of all available habitat could result in increased winter mortality for the pronghorn.

The size and stability of pronghorn winter home ranges appear to be important in the animal's ability to adapt to newly created unfavorable habitat situations. Bayless (1969) found the pronghorn's winter home range to average $10-11 \mathrm{~km}^{2}$, but one-half of the

\footnotetext{
Authors are principal range scientist, Intermountain Forest and Range Experiment Station, Shrub Sciences Laboratory, Provo, Utah 84601 ; and wildlife biologist, Utah Division of Wildlife Resources, Cedar City, Utah 84720.

Authors thank range technician John Kinney for his initiative and consistency of observation which made this study possible.

Manuscript received Jan. 21, 1983.
}

animals observed shifted home range at least once during the winter. This suggests that pronghorns may be flexible in their selection and use of wintering areas, although Howard et al. (1980) reported pronghorn avoided rough, broken terrain.

\section{Methods}

Pronghorn distribution on the Desert Experimental Range was systematically observed during the winters of 1976-77 through 1980-81. Total pronghorn numbers during this period increased from 80 to approximately 230 . Observations generally began in November and continued until the pronghorn herds were dispersing in the spring - usually in April. Observations were made by the unaided eye and by use of binoculars and spotting scopes along a vehicular travel route. The observation route included $106 \mathrm{~km}$ of observation and about $144 \mathrm{~km}$ of total travel. The route was followed twice each week in the winter of 1979-80 and once each week during other winters. Some weeks no observations were made because of severe weather conditions.

The pronghorn counts were summarized for each of 11 grazing units for each observation date. Pronghorn counted on the observation route did not constitute an estimate of the total population, therefore, calculated densities were considered as "relative densities". Relative pronghorn densities were determined by dividing the observed number of animals by the area available in each grazing unit. The area available for pronghorn use on the Desert Experimental Range totaled $142 \mathrm{~km}^{2}$.

Herded sheep used the area a portion at a time, spending 1 to 3 weeks on each grazing unit of 500 to 2400 ha. Each year, 2 units were grazed by domestic sheep in early winter, 3 in midwinter, 2 in late winter, 3 were rested, and 1 unit was always ungrazed. The pronghorn count-data were summarized into pregrazing and postgrazing periods for each range unit grazed by sheep. During the short periods of sheep grazing, data were insufficient to allow analysis of pronghorn response to the actual presence of sheep. For those units that were rested during the entire winter, the data were divided at February 1 to represent early and late winter periods. The differences between periods (pregrazing or postgrazing, early or late winter) were analyzed by $t$-test, using pronghorn density per grazing unit per date as the sample unit (Snedecor and Cochran 1967). The number of sample units per situation tested varied from 40 to 114.

Pronghorn observations were plotted on maps of the Desert Experimental Range. Chi-square comparisons were made to determine if pronghorn exhibited pronounced plant community or topographic site preferences during the winter period (Snedecor and Cochran 1967).

Some pronghorns had been collared during previous studies by Utah Division of Wildlife Resources. The collars provided an opportunity to determine movements and area selection of specific animals.

\section{Results and Discussion}

\section{Relationship of Pronghorn Distribution to Sheep Graxing}

An initial analysis of pronghorn distribution was conducted for the winter of 1979-80 because the frequency of observations had 


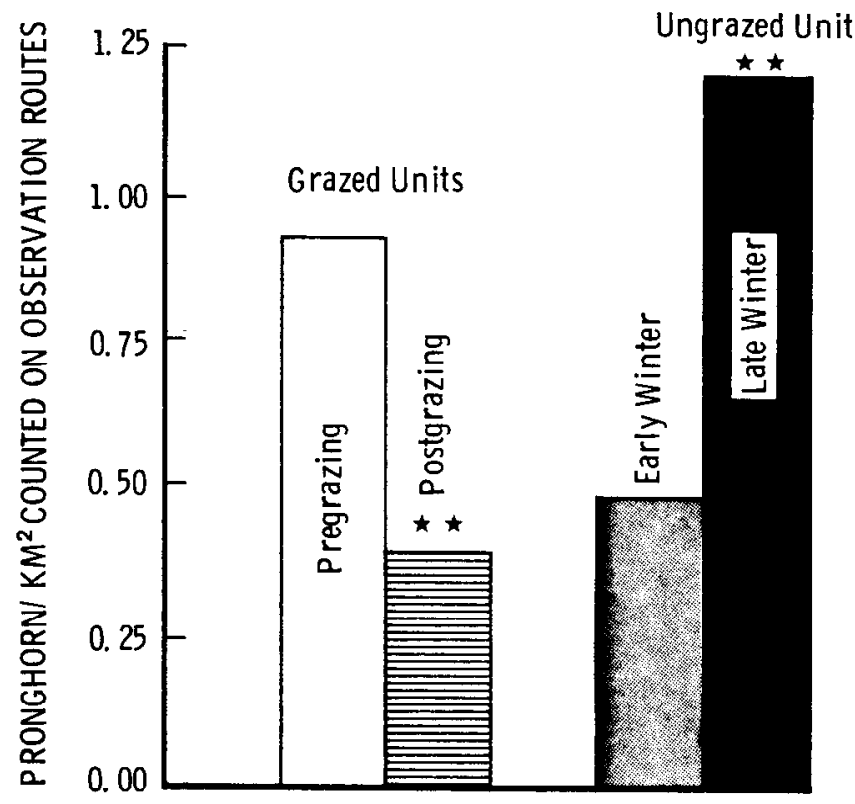

Fig. 1. Relative pronghorn densities (winter of 1979-80). Double star $(* *)$ indicates significance at 0.01 level.

been doubled during that period. Seven units were grazed by sheep in 1979-80. The relative pronghorn density observed per day was $0.93 \pm .18 / \mathrm{km}^{2}( \pm \mathrm{SE})$ in the pregrazing period (Fig. 1). In comparison, the relative density of pronghorn in these same units after grazing was only $0.32 \pm .04 / \mathrm{km}^{2}$-a significant reduction $(P \leq .01)$. The opposite trend occurred on the four grazing units that remained ungrazed the entire winter. The relative pronghorn density was $0.38 \pm .09 / \mathrm{km}^{2}$ in the early portion of the winter, but this increased significantly $(P \leq .01)$ to $1.20 \pm .14 / \mathrm{km}^{2}$ on the same ungrazed units in the last half of the winter. The changes in densities on these units strongly suggest that, although sheep grazing was moderate, the pronghorn found the grazed units relatively unfavorable for their use and therefore tended to concentrate in the remaining ungrazed units during the latter part of the wintcr.

The remaining years of data were examined to determine if their results supported the initial analysis. Three test situations were available.

a. The winters of 1976-77 and 1977-78, which were combined for analysis because of small sample sizes.

b. The winter of 1978-79, during which no sheep grazing occurred and immediately preceded the initial test winter.

c. The winter of 1980-81, which immediately followed the initial test winter.

Data obtained during 1976-77 and 1977-78 supported the previous analysis. Relative pronghorn densities dropped significantly $(P \leq .05)$ from $0.46 \pm .07 / \mathrm{km}^{2}$ before grazing to $0.21 \pm .06 / \mathrm{km}^{2}$ after grazing (Fig. 2). Relative densities appeared to increase in the late winter period for ungrazed units, but the change was not significant $(P>.05)$.

The Desert Experimental Range was not grazed by sheep the winter of 1978-79, and so provided an opportunity to determine if our observations of pronghorn densities were consistent from early winter to late winter. This appeared to be true as the early winter mean relative density $\left(0.90 \pm .20 / \mathrm{km}^{2}\right)$ was very similar to the late winter relative density $\left(0.80 \pm .21 / \mathrm{km}^{2}\right)$. Additional $t$-tests were made to determine if significant density changes occurred through the winter on those groups of units that showed change during the 1979-80 winter. These tests showed no significant changes $(P>.05)$ in pronghorn densities among units when no sheep were on the range.

Observations in the winter of 1980-81, when pronghorns numbered approximately 230 , strongly reinforced the earlier results. Relative densities were only about one-fifth as high after grazing as they were during the pregrazing period $\left(0.53 \pm .11 / \mathrm{km}^{2}\right.$ as opposed to $2.83 \pm .47 / \mathrm{km}^{2}$ ) on the grazed units (Fig. 2). Likewise, relative densities on ungrazed units showed a strong increase in late winter as compared to early winter $\left(1.14 \pm .15 / \mathrm{km}^{2}\right.$ as opposed to $0.51 \pm$ $.13 / \mathrm{km}^{2}$ ). The changes in relative pronghorn densities on both grazed and ungrazed units were highly significant $(P \leq .01)$ for 1980-81.

These findings clearly show that even moderate use by sheep ( 1 ha/sheep month) renders the range less favorable for pronghorn

\section{Grazed Units}

All Units Ungrazed

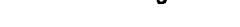

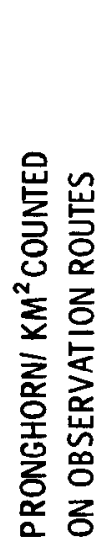

Ungrazed Units

$1976-77$ and $1977-78$

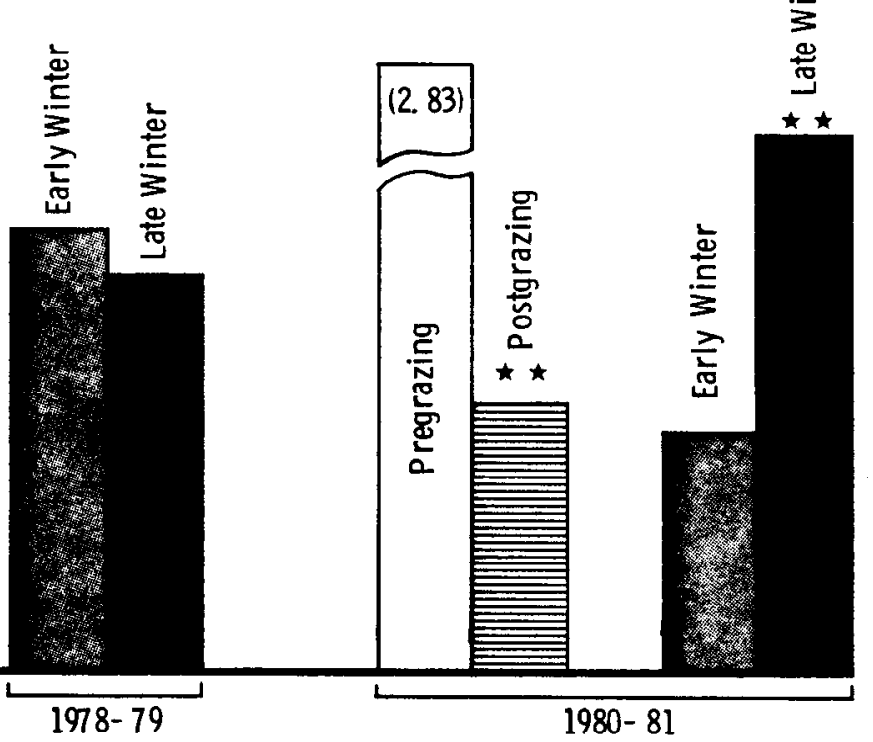

WINTERS

Fig. 2. Relative pronghorn densities for all winter except 1979-80. Single star (*) indicates significance at 0.05 level, double star (**) indicates significance at 0.01 level. 
Table 1. Comparison of pronghorn and plant community distribution.

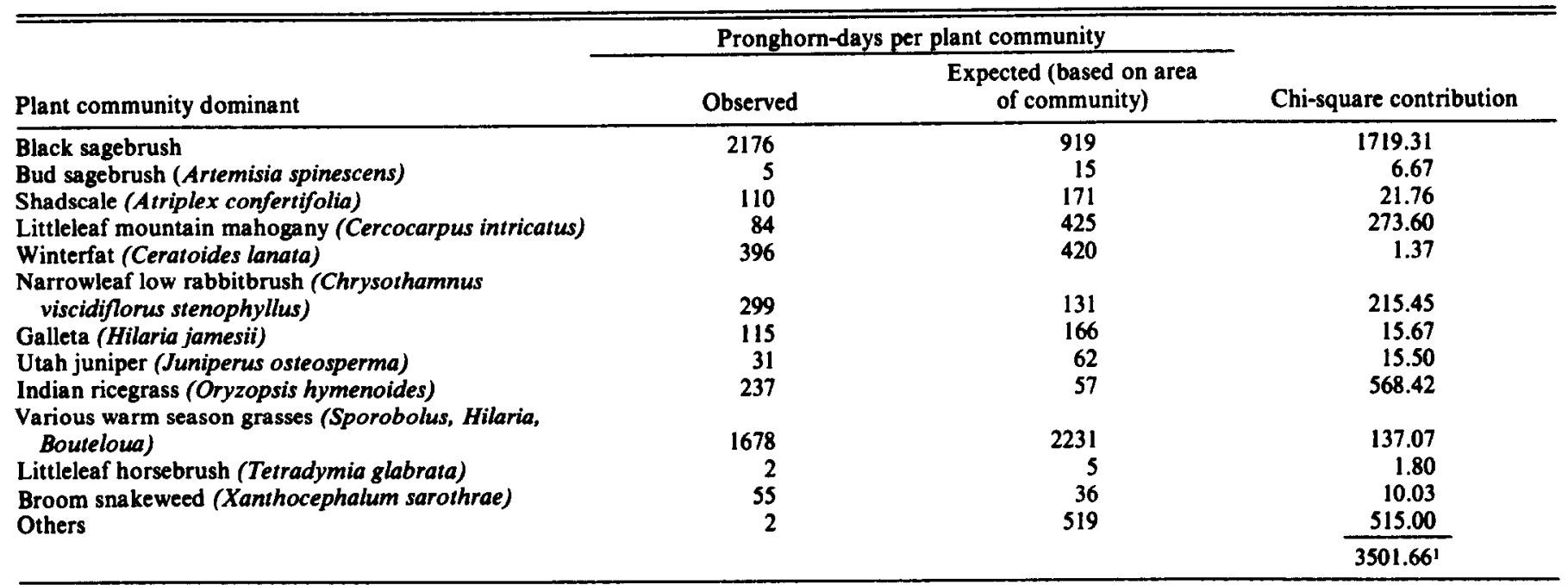

IGreatly exceeds table value $(\alpha=0.01)$ of 26.22 .

until the new spring growth begins. At that time, on the Desert Experimental Range, the pronghorn disperse to all units-presumably because new green forage is available and previous dormant-season grazing by sheep no longer has a significant effect.

The prime factor in the avoidance of sheep-grazed units is likely dietary competition for black sagebrush (Artemisia nova) (Smith and Beale 1980). This species is a dominant component of pronghorn winter diets on the Desert Experimental Range (Beale and Smith 1970), and also highly preferred by sheep (Hutchings and Stewart 1953). Because in many areas of the Desert Experimental Range production of black sagebrush does not exceed $11 \mathrm{~kg} / \mathrm{ha}$, little remains of this preferred plant after sheep have grazed an entire unit.

No statistical evidence was found that pronghorn density or use was related to the previous winter's sheep grazing. Pronghorn density was only related to the current winter's sheep grazing.

\section{Relationship of Pronghorn Distribution to Plant Communities}

The distribution of pronghorns was examined in relation to the distribution of plant communities. Vegetation was grouped into 13 broad communities based on the dominant species. Chi-square comparisons were made to determine if the distribution of pronghorn observations among the various community categories was in proportion to the area of the communities (Table 1). Observations for the early and late periods of the winters of 1979-80 and 1980-81 were pooled to examine average winter distributions. A very high calculated chi-square value $\left(X^{2}=3,502\right)$ suggests that few plant communities received pronghorn use proportionate to their area $(P \leq .01)$. The largest contribution to the calculated chi-square value was from black sagebrush-dominated communities, which received 2 to 3 times as much pronghorn use as would be expected based on area occupied. Several other communities experienced higher than expected use, for example, those dominated by low rabbitbrush and Indian ricegrass. These small communities occurred in part near watering locations and also had small drainages within them which supported black sagebrush. Pronghorn made little use of communities dominated by summer-growing grasses, gray molly (Kochia americana), and the open playa. Pronghorn also appeared to make little use of littleleaf mountain mahogany, but too much of this community was inaccessible to observers to support a definite conclusion.

\section{Relationship of Pronghom Distribution to Slope and Aspect}

Although pronghorn have a reputation for avoiding rough country, that is not necessarily the case on the Desert Experimental Range. Eleven percent of the area available to pronghorn had slopes in excess of $33 \%$; however, $18 \%$ of the animal observations were on these slopes-a significant response ( $P \leq 01)$. These obser- vations were concentrated on the slopes with black sagebrush communities. Steep slopes dominated by littleleaf mountain mahogany were apparently little used. Therefore, location of plant communities appeared to be more significant to pronghorn distribution than the slope steepness.

Pronghorn also responded significantly $(P \leq .01)$ to directional aspect during these winter periods. The proportion of observations was approximately $50 \%$ higher on warm aspects $(\mathrm{S}, \mathrm{SW}$, and $\mathrm{W})$ than would be expected based on area occupied by these aspects. In addition, observations in late winter on nearly level (ca. $21 / 2 \%$ slope) valley floors were about $75 \%$ greater than expected as pronghorn dispersed during March and April.

\section{Observation of Marked Animals}

Twenty-six pronghorn were individually identifiable because of marked collars placed on them during earlier studies. Movements of individuals observed 6 or more times per winter were mapped and studied. The observations per individual studied varied from

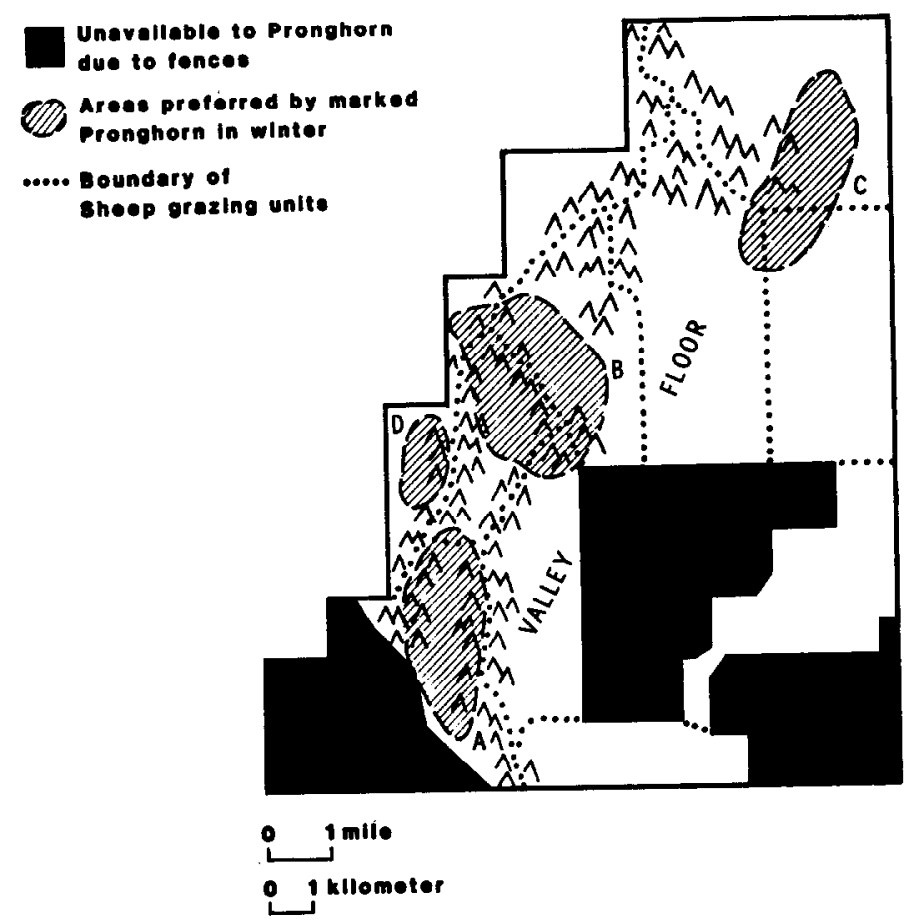

Fig. 3. Location of areas on the Desert Experimental Range preferred by marked pronghom in winter. 


\section{6-13 with an average of 9.}

In the winter of 1976-77, 14 individually identified females used 3 different areas of the Desert Experimental Range. Two spent the entire winter in about $2-3 \mathrm{~km}^{2}$ of area $A$ (Fig. 3), which was rested from sheep grazing. Seven females spent the winter in area $B$, which had no sheep grazing until March and April when some new green forage was available. The average observed winter use area (calculated by the method of Hayne 1949) for the 7 was $6 \mathrm{~km}^{2}$. One female divided her time between areas A and B and had a use area of $16 \mathrm{~km}^{2}$. Four females preferred the northeastern portion of the Desert Range (area C). Their winter use area varied from $11 / 2$ to 19 $\mathrm{km}^{2}$, but they all persisted in their use of area Ceven though it had been grazed by sheep in midwinter.

Five marked males exhibited similar winter use preference as the females. Two remained the entire winter in area $B, 1$ made alternate use of $A$ and $B, 1$ used only $C$, and 1 was observed in areas $A, B$, and $C$. The winter use areas of the males ranged from 5 to $40 \mathrm{~km}^{2}$, with a mean of $16 \mathrm{~km}^{2}$.

In the winter of $1977-78,9$ individually marked female pronghorn were observed at least 6 times each. Three of these began the winter in area $A$, but moved to area $D$ for the remainder of the winter after sheep grazing of area $A$. The average use area for the 3 was $7 \mathrm{~km}^{2}$ for the winter, but only about $1 \mathrm{~km}^{2}$ when in area $D$. One other animal occupied area $A$ until it was grazed by sheep, but it was not seen again until March when it was observed at the south edge of area B. It then moved to the valley floor. Five of the 6 remaining animals also spent considerable time in the relatively small area $D$. Four of these apparently traveled together, moving from the valley floor in November, across area B in December, then remained in area $D$ during midwinter. Two returned to the valley floor in March. The winter use area of these 4 averaged 15 $\mathrm{km}^{2}$; however, about one-half of their observations were within 1 $\mathbf{k m}^{2}$ of area $D$. The ninth animal was first seen with the above group shortly before they arrived at area D. It later moved to the valley floor in March.

Only 4 individuals were observed and identified 6 or more times in both winters. Of these 4,2 individuals used the same area both winters and 2 used different areas.

Relatively few of the moves by marked pronghorn appeared to be directly related to sheep herd movements. Most pronghorn moves were between units ungrazed by sheep. Some individuals seemed to move periodically, but were seldom observed in grazed units. Our interpretation is that the pronghorn, as part of their general movements, may have crossed grazed units, but spent relatively little time on them. Then, when they encountered an ungrazed unit with adequate forage, they perhaps lingered and were more apt to be observed there. This is somewhat different from initial interpretations that pronghorn seemed to remain in a winter grazing unit until sheep grazing competition forced them to move (Clary and Holmgren 1981). Pronghorn were regularly present in ungrazed preferred wintering areas, but based on the movements of individuals, the actual animals present may have changed through time.

Areas A, B, and D all have topography that varies from gently rolling to steep and broken (Fig. 3). Likewise all have substantial areas of black sagebrush-dominated plant communities, and a more varied botanical composition than that available in the more level valley bottoms. Area $\mathrm{C}$ differs somewhat from the previous 3 areas in that it has less steep topography and less black sagebrush. There are, however, numerous small ephemeral drainages that contain black sagebrush. The elevation of all 4 preferred areas is predominantly above $1,800 \mathrm{~m}$, which is likely above the boundary of the midwinter cold air inversions. ${ }^{1}$ Pronghorn on the Desert Range apparently respond to winter weather conditions because in the previous analysis it was shown they sought the warmer aspects. Protection from wind and the occurrence of warmer nighttime temperatures may have been factors in selection of winter use areas in addition to the relative abundance of their major diet speciesblack sagebrush.

\section{Conclusions}

Winter observations on the Desert Experimental Range show a statistically definable pattern of reduced densities of observed pronghorn on units grazed by sheep and that these densities remained low until spring plant growth had begun. The interpretation is that even moderate sheep use during the dormant period leaves grazing units relatively unfavorable for pronghorn until regrowth occurs-at least on ranges where the key pronghorn forage plants are in short supply.

The winter distribution of pronghorn is strongly affected by plant community distribution. Pronghorn used black sagebrush areas at 2-3 times the amounts expected based on areal coverage even though many of the black sagebrush-dominated communities were on quite steep topography. Pronghorn did not appear to avoid slopes in excess of $33 \%$ if black sagebrush communities were present; in fact pronghorn may have preferred broken topography that could attenute severe winter conditions.

The presence of ungrazed areas on the Desert Experimental Range each winter seems to have been important in reducing competitive impacts of sheep grazing (Clary and Holmgren 1981). Periodic movements of pronghorn were a mechanism in their apparent ease in finding areas ungrazed by sheep. If most pronghorn had remained in small specific areas throughout the winter, the presence of rested grazing units available several miles away would have been of little benefit. Likewise, when other uses of the desert affect specific winter range areas, pronghorn can apparently easily relocate if the proper plant communities are available. Permanent destruction of habitat, however, would obviously lead to long-term reduction of pronghorn populations if they are forced to continuously over-concentrate on favorable habitats.

\section{Literature Cited}

Autenrieth, R. (ed.).1978. Guidelines for the management of pronghorn antelope. p. 473-526. In: Proc. Eighth Biennial Pronghorn Antelope Workshop. Jasper, Alta., Canada.

Bayless, S.R. 1969. Winter food habits, range use, and home range of antelope in Montana. J. Wildl. Manage. 33:538-551.

Beale, D.M., and R.C. Holmgren. 1975. Water requirements for pronghorn antelope fawn survival and growth. Final Rep., Fed. Aid Proj. W-65-RD-23, Job B-4. Utah Div. Wildl. Resour., Salt Lake City.

Beale, D.M., and A.D. Smith. 1970. Forage use, water consumption, and productivity of pronghorn antelope in western Utah. J. WildI. Manage. 34:570-582.

Beale, D.M., and A.D. Smith. 1973. Mortality of pronghorn antelope fawns in western Utah. J. Wildl. Manage. 37:343-352.

Clary, W.P., and R.C. Holmgren. 1981. Observations of pronghorn distribution in relation to sheep grazing on the Desert Experimental Range. p. 581-592. In: Proc. Wildlife-Livestock Relationships Symp. Dep. Wild. Res. Univ. Idaho, Moscow, Ida.

Hayne, D.W. 1949. Calculation of the size of home range, Montana. J. Mammalogy 30:1-18.

Howard, V.W., Jr., L. LaPlant, and A. Lara. 1980. Antelope studies in southeastern New Mexico. p. 132-150. In: Proc. Ninth biennial Pronghorn Antelope Workshop. Rio Rico, Ariz.

Hutchings, S.S., and G. Stewart. 1953. Increasing forage yields and sheep production on Intermountain winter ranges. USDA Cir. 925, Washington, D.C.

Kindschy, R., C. Sundstrom, and J. Yoakum. 1978. Range/wildlife interrelationships-pronghorn antelope. p. 216-269. In: Proc. Eighth Biennial Pronghorn Antelope Workshop. Jasper, Alta., Canada.

Salwasser, H. 1980. Pronghorn antelope population and habitat management in the northwestern Great Basin environments. USDA Forest Serv. Pacific Southwest Region.

Smith, A.D., and D.M. Beale. 1980. Pronghorn antelope in Utah; some research and observations. Utah Div. Wildl. Res. Pub. 80-13.

Snedecor, G.W., and W.G. Cochran. 1967. Statistical methods. Iowa State University Press, Ames.

Yoakum, J. 1980. Habitat management guides for the American pronghorn antelope. US Dep. Interior, Bureau of Land Manage., Tech. Note 347. Denver Service Center, Denver, Colo.

'Ralph C. Holmgren, Provo, Utah, personal communication. 